\title{
Diel vertical migration of predators (planktivorous fish larvae) and prey (zooplankton) in a tropical lagoon
}

\author{
Marcos Marques Mendonça' ${ }^{1}$ Pablo Henrique dos Santos Picapedra², \\ Michelli Caroline Ferronato' \& Paulo Vanderlei Sanches ${ }^{1,3}$
}

\begin{abstract}
1. Programa de Pós-Graduação em Recursos Pesqueiros e Engenharia de Pesca, Universidade Estadual do Oeste do Paraná, Rua da Faculdade, 645, 85903-000 Jardim La Salle Toledo, PR, Brazil.

2. Programa de Pós-Graduação em Biologia Comparada, Universidade Estadual de Maringá, Av. Colombo, 5790, 87020-900 Maringá, PR, Brazil.

3. Centro de Ciências Exatas e Engenharias, Programa de Pós-Graduação em Ciências Ambientais, Grupo de Pesquisas em Recursos Pesqueiros e Limnologia Universidade Estadual do Oeste do Paraná, Rua da Faculdade, 645, 85903-000, Jardim La Salle Toledo, PR, Brazil. (marcos-181 $1 @$ hotmail.com)
\end{abstract}

\begin{abstract}
Based on the hypothesis that diel vertical migration (DVM) is a mechanism of predator avoidance, the objective of the present study was to test for the occurrence of DVM in planktivorous fish larvae of Hypophthalmus edentatus (Spix, 1829) (Siluriformes, Pimelodidae) and Plagioscion squamosissimus (Heckel, 1840) (Perciformes, Sciaenidae), and zooplankton (rotifers, cladocerans and copepods) in an isolated tropical lagoon in the floodplain of the Upper Paraná River, Brazil (region of Parque Nacional de Ilha Grande). We investigated spatial overlap between predators (planktivorous fish larvae) and prey (zooplankton), and tested which physical and chemical variables of the water are related to the DVM of the studied communities. We performed nocturnal $(8: 00 \mathrm{pm}$ and 4:00 am) and diurnal sampling $(8: 00 \mathrm{am}$ and 4:00 pm) in the limnetic region of the lagoon for six consecutive months, from October 2010 to March 2011, which comprises the reproductive period of the fish species analyzed. During the day the larvae tried to remain aggregated in the bottom of the lagoon, whereas at night they tried to disperse in the water column. Especially for cladocerans, the diel vertical migration is an important behavior to avoid predation larvae of H. edentatus and P. squamosissimus once decreased spatial overlap between secured and its potential predators, which corroborates the hypothesis that DVM is a mechanism of predator avoidance. Although significant correlations were observed between the abiotic factors and WMD of microcrustaceans at certain times of day, the effect of predation of fish larvae on zooplankton showed more important in this environment, because the small depth and isolation not allow great variation of abiotic factors seasonally and between strata the lagoon.
\end{abstract}

KEYWORDS. Vertical distribution, spatial overlap, predator-prey interactions, rotifers, microcrustaceans.

RESUMO. Migração vertical diária de predadores (larvas de peixes planctívoras) e presas (zooplâncton) em uma lagoa tropical. Com base na hipótese de que a migração vertical diária (MVD) é um mecanismo que visa evitar predadores, o objetivo do presente estudo foi verificar a ocorrência de MVD em larvas de peixes planctívoras de Hypophthalmus edentatus (Spix, 1829) (Siluriformes, Pimelodidae) e Plagioscion squamosissimus (Heckel, 1840) (Perciformes, Sciaenidae), e nos grupos zooplanctônicos (rotíferos, cladóceros e copépodes) em uma lagoa tropical isolada da planície de inundação do alto rio Paraná, Brasil (região do Parque Nacional de Ilha Grande). Foi investigada a sobreposição espacial entre predadores (larvas de peixes) e presas (zooplâncton), bem como verificar quais variáveis físicas e químicas da água estariam relacionadas com a MVD das comunidades envolvidas neste estudo. Foram realizadas amostragens noturnas (20:00 e 4:00) e amostragens diurnas (8:00 e 16:00) na região limnética da lagoa durante um período de seis meses consecutivos, entre outubro de 2010 a março de 2011, que compreende o período reprodutivo das espécies de peixes analisadas. Durante o dia, as larvas permaneceram agregadas no fundo da lagoa, enquanto à noite procuraram dispersar-se na coluna de água. Principalmente para os cladóceros, a migração vertical diária foi um comportamento importante para evitar a predação das larvas de $H$. edentatus e P. squamosissimus, uma vez que diminuiu a sobreposição espacial entre presa e seu predador em potencial, dando suporte à hipótese de que a migração vertical é um mecanismo de defesa contra a predação. Embora correlações significativas foram observadas entre os fatores abióticos e a profundidade média ponderada dos microcrustáceos em determinados períodos do dia, o efeito da predação das larvas de peixes sobre o zooplâncton mostrou ser mais importante neste ambiente, visto que a pequena profundidade e o isolamento não permiti grandes variações dos fatores abióticos sazonalmente e entre os estratos da lagoa.

PALAVRAS-CHAVE. Distribuição vertical, sobreposição espacial, interação presa-predador, rotíferos, microcrustáceos.

The study of the spatial components of a food chain is a research field with high potential, which aims at bringing new perspectives to studies on ecosystem functioning (Ciannelli et al., 2007; KempF et al., 2008). Predation is recognized as one of the main factors that influence the dynamics and structure of communities, as predators affect the morphology, physiology, life history, and behavior of their prey (SiH, 1987). The prey can reduce predation pressure by avoiding encounters with the predator. The most important behavioral response that the zooplankton exhibits against predators is diel vertical migration (DVM) (Bezerra-Neto \& Pinto-Coelho, 2002). DVM effectively reduces predation risk by reducing the spatial overlap between prey and predator populations (WiLliamson, 1993).
Understanding the temporal and spatial dynamics of predator-prey interactions is one of the most important issues in aquatic ecology (LORKE et al., 2004; BEZERRANeto \& Pinto-Coelho, 2012). Many zooplankton species exhibit some sort of DVM in lakes, seas, and reservoirs (HAYs, 2003). This behavior can vary between and within species, as well as seasonally. It has been interpreted by several authors as a defense against predation, in which the prey avoids parts of the water column where predation pressure is high (ZARET \& SUFFERn, 1976; OHMAN, 1990; Bezerra-Neto \& Pinto-Coelho, 2007).

In planktonic communities, the predation risk for a given type of prey can be estimated based on two primary components: prey vulnerability and density risk, which is a function of predator density and spatial and temporal overlap 
between predator and prey populations (WILLIAMSON \& StOeCKel, 1990). Prey-predator interactions are, therefore, strongly dependent on the spatial distribution of predator and prey, and DVM may represent an effective mechanism to minimize the risk of predation by tactile and visual predators (SiH, 1987; WiLliamson, 1993).

The fish larvae of the ichthyoplankton are essential components of the pelagic compartment, and through predation and food selectivity they promote differences in zooplankton composition, both in terms of species and size of organisms (BöING et al., 1998). In spite of their planktonic nature, fish larvae can control their vertical position in the water column. Hence, vertical migration plays an important role in survival, allowing the larvae to occupy areas favorable to their survival (ACEves-Medina et al., 2008; TAMAKI et al., 2010).

Only a few studies on the interaction of fish and zooplankton have been carried out in Brazilian floodplains (e.g., PiCAPEDRA et al., 2015). In the field of fish-environment interactions stand out the studies by Zaret (1984) and Previatelli \& Santos- Silva (2011), which assessed zooplankton consumed by fish in terms of composition, distribution, and density in floodplain lakes. It has been shown that zooplanktonic organisms can alter their migratory behavior in response to predators (DODSON, 1988). However, analyses of DVM in zooplankton in the wild with a focus on the role of the prey-predator spatial overlap are still scarce. Furthermore, there are no studies on the zooplanktonic and fish communities in recently isolated environments that no longer receive the influence of the flood pulse.

In the present study, we evaluated the occurrence of the of DVM in planktivorous fish larvae of Hypophthalmus edentatus (Spix, 1829) (Siluriformes; Pimelodidae) and Plagioscion squamosissimus (Heckel, 1840) (Perciformes; Sciaenidae), and zooplankton (rotifers, cladocerans and copepods) in an isolated tropical lagoon in the floodplain of the Upper Paraná River, Brazil (region of Parque Nacional de Ilha Grande). We investigated spatial overlap between predators (planktivorous fish larvae) and prey (zooplankton), and tested which physical and chemical variables of the water are related to the DVM of the studied communities.

\section{MATERIAL AND METHODS}

Study area. The Xambrê Lagoon (2352' ${ }^{\circ}$ 'S; $54^{\circ} 0^{\prime} 12^{\prime \prime} \mathrm{W}$ ) is located on the left margin of the Paraná River, in the region of Parque Nacional de Ilha Grande PR/MS. The Parque Nacional de Ilha Grande was created by federal decree no number on September 30, 1997, currently ICMBio manager organ (Instituto Chico Mendes de Conservação da Biodiversidade). The Xambrê Lagoon has approximately $5 \mathrm{~km}$ in length, $1 \mathrm{~km}$ in width, and depth ranging from 3 to $6 \mathrm{~m}$. There is a vast floodplain composed of shrubby vegetation and aquatic macrophytes on the right margin that separates the lagoon from the Paraná River. On the left margin, there are small stretches of riparian forest and large stretches of shrubby vegetation and grass. Previously, this lagoon had contact with the Paraná River in flood periods, but with the flow control imposed by the operation of the Engenheiro Sergio Motta hydropower plant (UHE Porto Primavera), which has started in the early 1998 , the lagoon has been isolated and is maintained only by groundwater and a small stream (DAGA et al., 2009) (Fig.1).

Sampling. We sampled zooplankton and larvae of H. edentatus and P. squamosissimus in the central region of the Xambrê Lagoon in two diurnal times (8:00 am and 4:00 pm) and two nocturnal times (8:00 pm and 4:00 am), every month from October 2010 to March 2011. We carried out collection close to the surface and in the bottom of the lagoon. For the analysis of the vertical distribution of the organisms throughout months, we grouped day (8:00 am and 4:00 pm) and night sampling times (8:00 pm and 4:00 am). We sampled zooplankton with a motor pump, both on the surface and in the bottom; 200 liters of water were filtered per sample in a $68-\mu \mathrm{m}$-mesh conical net. We placed the collected material in polyethylene flasks, properly labeled, and fixed in a formaldehyde solution at $4 \%$ buffered with calcium carbonate.

To sample fish larvae on the surface we used a conical-cylindrical plankton net, with $0.5 \mathrm{~mm}$ mesh and a flowmeter coupled to its mouth to measure the volume of filtered water; the net was dragged by low-speed boats. For the bottom sampling we used a plankton net with the same mesh size coupled to an sled-shaped iron frame. Both nets were equipped with a mechanic flowmeter (Flowmeter General Oceanics ${ }^{\mathrm{TM}}$ ) to measure the volume of the filtered water. We previously anesthetized the captured individuals with eugenol (4-Allyl-2-Methoxyphenol) and, then, fixed them in a formaldehyde solution at $4 \%$ buffered with calcium carbonate. Concomitantly to plankton sampling, we took water samples to determine the values of some abiotic variables, such as $\mathrm{pH}$, water temperature $\left({ }^{\circ} \mathrm{C}\right)$, electrical conductivity $(\mu \mathrm{S} / \mathrm{cm})$, and dissolved oxygen $(\mathrm{mg} / \mathrm{L})$, all measured with portable digital devices. We collected water samples from the bottom with a 5 liters Van Dorn bottle.

Laboratory analysis. To determine zooplankton density we carried out sub-sampling with a Hensen-Stempell pipette $(2.5 \mathrm{~mL})$ and counted at least 50 individual rotifers, cladocerans, and juveniles (nauplii and copepodids), and adult copepods in a Sedgewick-Rafter chamber under an optical microscope. Organism counting followed BotTRELL et al. (1976); we took three subsamples from each sample collected. The samples with a small number of individuals were counted in full. Total density was expressed in ind. $\mathrm{m}^{3}$. The individuals were identified using specialized taxonomic literature (Koste, 1978; ReID, 1985; Matsumura-TundisI, 


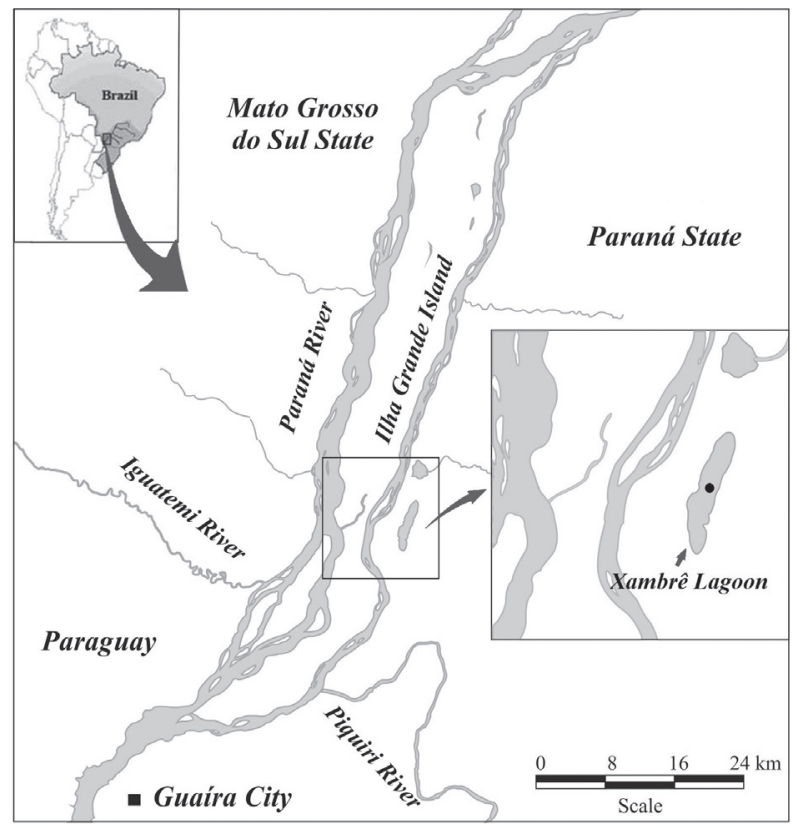

Fig. 1. Location of the sampling site in the Xambrê Lagoon, Parque Nacional de Ilha Grande (Altônia, Paraná, Brazil).

1986; SEgERs, 1995; ELMOOR-LOUREIRO, 1997; LANSACTôHA et al., 2002).

For the analysis of ichthyoplankton, we separated the fish larvae from the rest of the plankton using a stereoscopic microscope with a magnification of $10 \mathrm{x}$ and a Bogorov plate. We identified the larvae considering all morphometric characteristics listed by NAKATANI $e t$ al. (2001), and the nomenclature followed ReIs et al. (2003). The data of total larvae density were standardized for a volume of $10 \mathrm{~m}^{3}$ of filtered water, following TANAKA (1973), modified by NAKATANI et al. (2001).

Statistical analysis. The relative importance of physical and chemical variables of the water in determining the vertical position of the fish larvae and zooplankton was evaluated through stepwise logistic regressions performed day and night samples. The weighted mean depths of the fish larvae and zooplankton population were considered dependent variables. As independent variables $\mathrm{pH}$, temperature, dissolved oxygen, and electrical conductivity. To obtain normality, weighted mean depths of the fish larvae and zooplankton population, and independent variables underwent log transformation. We performed this analysis in the software Statistica ${ }^{\mathrm{TM}}$ version 7.1 (StATSOFT INC., 2005). The significance level adopted was $p<0.05$.

For the analysis of vertical distribution of organisms we calculated the mean depth at 8:00 pm, 4:00 am, 8:00 am and 4:00 pm for each zooplanktonic group and for the fish larvae of $H$. edentatus and P. squamosissimus, according to the equation of weighted mean depth (WMD) by FrosT \& BOLLENS (1992):

$$
W M D=\left(\sum \text { nidi }\right) /\left(\sum n i\right)
$$

where $n_{i}$ is the density (individuals per $\mathrm{m}^{3}$ ) of the population $i$ and $d_{i}$ is the depth of the sample $i$, which is considered the midpoint of each depth stratum.

We calculated the amplitude of vertical migration as the difference between the mean depth of the organism $i$ during the day and the night. As a criterion for determining DVM behavior we tested for differences in the WMD mean between day and night using a two-tailed t test. We considered the occurrence of DVM when the difference in the WMD mean between day and night was significant ( $p$ $<0.05)$. We determined migration amplitude $(\Delta \mathrm{Z})$ by the difference between WMD day and night; positive values indicate normal DVM and negative values indicate reverse DVM.

To understand the variations in zooplankton and fish larva populations in the water column, we calculated the overlap index, using the equation described by WILLIAMSON \& STOECKel (1990):

$$
O i j=\sum_{z=1}^{m}(N j z n i z) m / \sum_{z=1}^{m}(N j z) \cdot \sum_{z=1}^{m}(n i z)
$$

where $z$ represents depth, $m$ is the number of depths sampled, $N j z$ is the density of the predator $i$, and niz is the density of the prey $i$. The values of $O i j$ vary from zero (no overlap) to the upper limit (total overlap), which is defined by the number of depths sampled. If predator and prey are uniformly distributed in the water column, $O i j=1$; values $<1$ indicate some degree of aggregation between the studied species in some stratum of the water column.

\section{RESULTS}

We observed low variation in the abiotic variables between the strata and periods analyzed; we did not record the occurrence of sharp stratification. The $\mathrm{pH}$ showed gradients below 1, remaining close to neutrality along almost all months. Only in January we recorded lower values in strata and periods (Fig. 2). We recorded the lowest values of dissolved oxygen at night in all months analyzed, especially in November (Fig. 3). However, even the lowest values did not restrict the survival of organisms. Similarly to dissolved oxygen, temperature was lower at night, with differences between surface and bottom varying between 1 and 1.5 between night and day (Fig. 4). The values of electrical conductivity showed high difference between surface and bottom only in October $\left(24.6 \mu \mathrm{S} . \mathrm{cm}^{-1}\right)$; in other months there was low variation, with values below $50 \mu \mathrm{S} . \mathrm{cm}^{-1}$ (Fig. 5).

The correlation between WMD fish larvae and zooplankton with WMD physical and chemical variables of the water pointed to one negative and significant correlation between cladocerans and $\mathrm{pH}$ in the day $\left(r^{2}=0.81 ; p=\right.$ $0.01)$ and two positive and significant correlations between copepod and temperature in the night $\left(r^{2}=0.74 ; p=0.02\right)$ and dissolved oxygen in the day $\left(r^{2}=0.68 ; p=0.04\right)$. There was no other significant correlation between the WMD of 

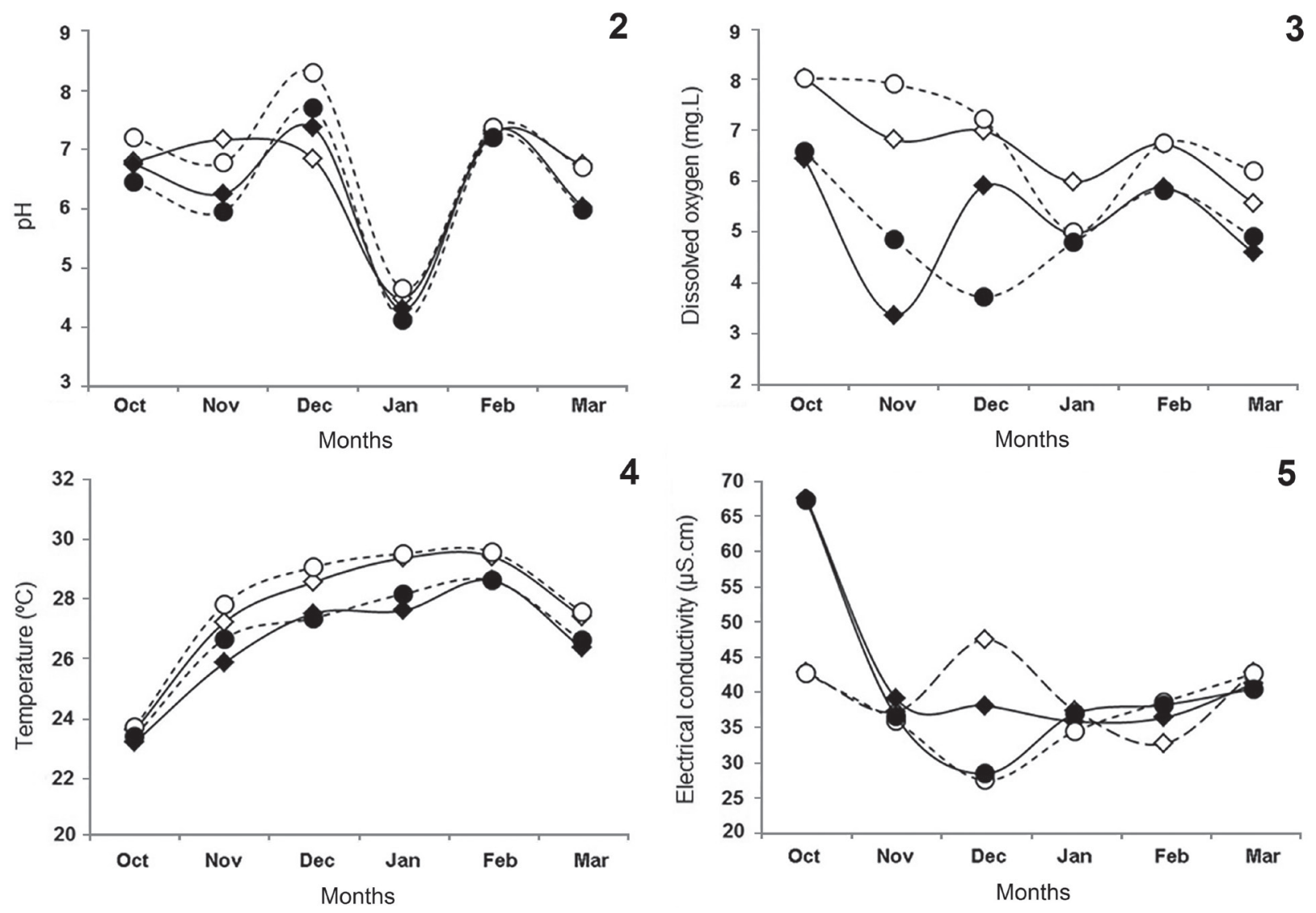

\section{O Surface - Day $\bullet$ Bottom - Day $\diamond$ Surface - Night $\bullet$ Bottom - Night}

Figs 2-5. Variation of $\mathrm{pH}$ (2), dissolved oxygen (3), temperature (4) and electrical conductivity (5) during the day and night at the surface and on the bottom in the Xambrê Lagoon, Parque Nacional de Ilha Grande, Brazil during October 2010 to March 2011.

these organisms physical and chemical variables of the water (Tab. I).

The larvae densities of $H$. edentatus and $P$. squamosissimus differed significantly $(p<0.05, t$ test $)$ during the day (8:00 am and 4:00 pm) (Figs. 8, 9), when there was concentration in the bottom of the lagoon. At night (8:00 pm and 4:00 am) (Figs. 6, 7) the larvae dispersed between strata, especially at 4:00 am (Fig. 7). Diurnal captures of $H$. edentatus were restricted to November at 4:00 pm (Fig. 9), whereas captures of $P$. squamosissimus were restricted to December and January at 8:00 am (Fig. 8) and January at 4:00 pm (Fig. 9).

In general, there were no significant differences in the density of zooplankton ( $p>0.05, t$ test) between lagoon strata and sampling periods. The density of rotifers varied from $4.1 \times 10^{3}$ ind. $/ \mathrm{m}^{3}$ in December to $82 \times 10^{3}$ ind. $/ \mathrm{m}^{3}$ in

Tab. I. Multiple linear regressions summary for fish larvae of the H. edentatus (Spix, 1829) and P. squamosissimus (Heckel, 1840) and rotifers, cladocerans and copepods WMDs using combined samplings daytime and nighttime dates in the Xambrê Lagoon, Parque Nacional de Ilha Grande, Brazil during October 2010 to March 2011 (values marked with an asterisk indicate significant correlations; $p<0.05$ ).

\begin{tabular}{|c|c|c|c|c|}
\hline \multirow[b]{2}{*}{ Fish larvae/Zooplankton } & \multicolumn{4}{|c|}{ Variables } \\
\hline & $\mathrm{pH}$ & Temperature & D. oxygen & E. conductivity \\
\hline \multicolumn{5}{|c|}{ Day } \\
\hline H. edentatus & 0.46 & 0.37 & 0.94 & 0.34 \\
\hline P. squamosissimus & 0.32 & 0.34 & -0.44 & -0.76 \\
\hline Rotifera & 0.34 & -0.05 & -0.38 & 0.56 \\
\hline Cladocera & $-0.90 *$ & 0.12 & -0.20 & 0.52 \\
\hline Copepoda & -0.24 & 0.64 & $0.83 *$ & 0.39 \\
\hline \multicolumn{5}{|c|}{ Night } \\
\hline H. edentatus & -0.62 & -0.86 & -0.69 & -0.60 \\
\hline P. squamosissimus & 0.11 & 0.10 & 0.59 & 0.50 \\
\hline Rotifera & 0.62 & 0.79 & 0.65 & 0.54 \\
\hline Cladocera & -0.07 & -0.05 & -0.11 & -0.57 \\
\hline Copepoda & 0.08 & $0.86^{*}$ & 0.35 & 0.76 \\
\hline
\end{tabular}



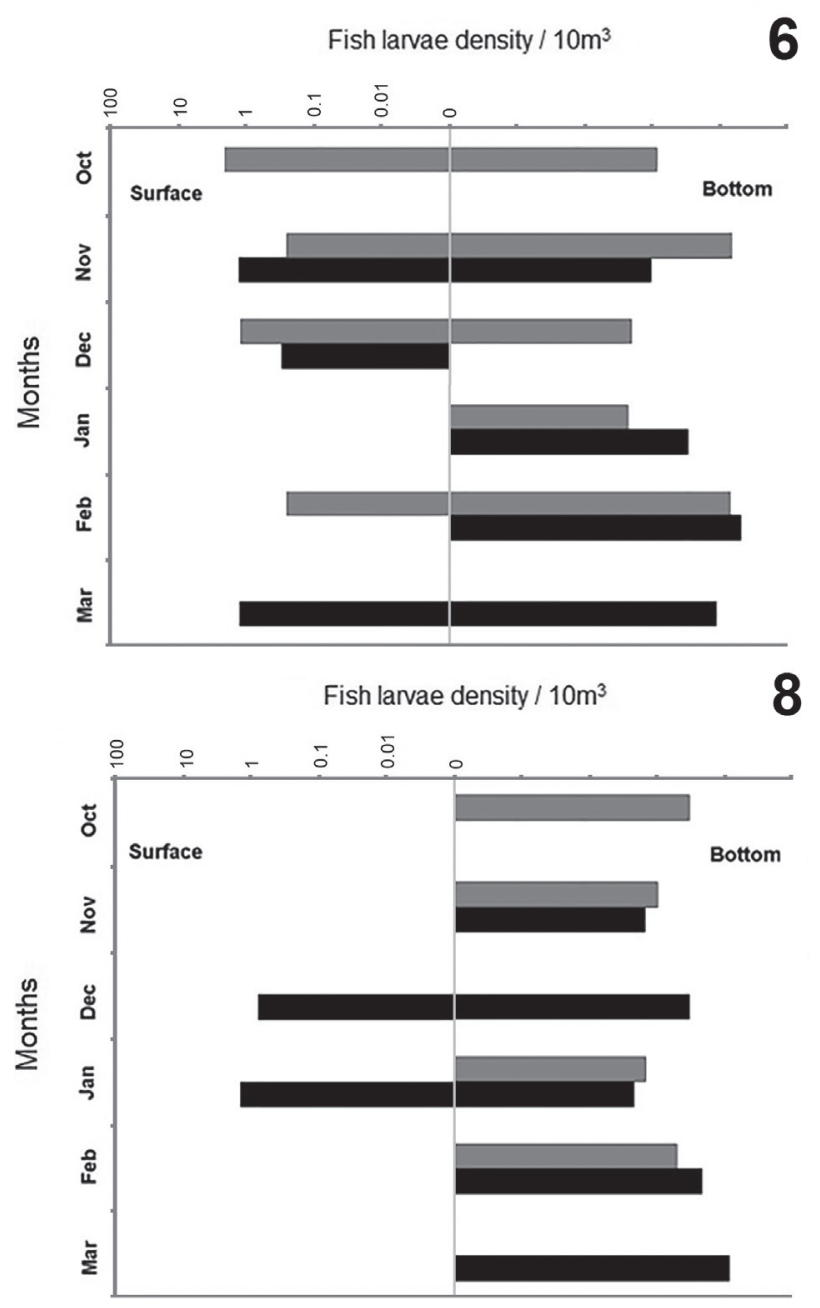

H. edentatus

8
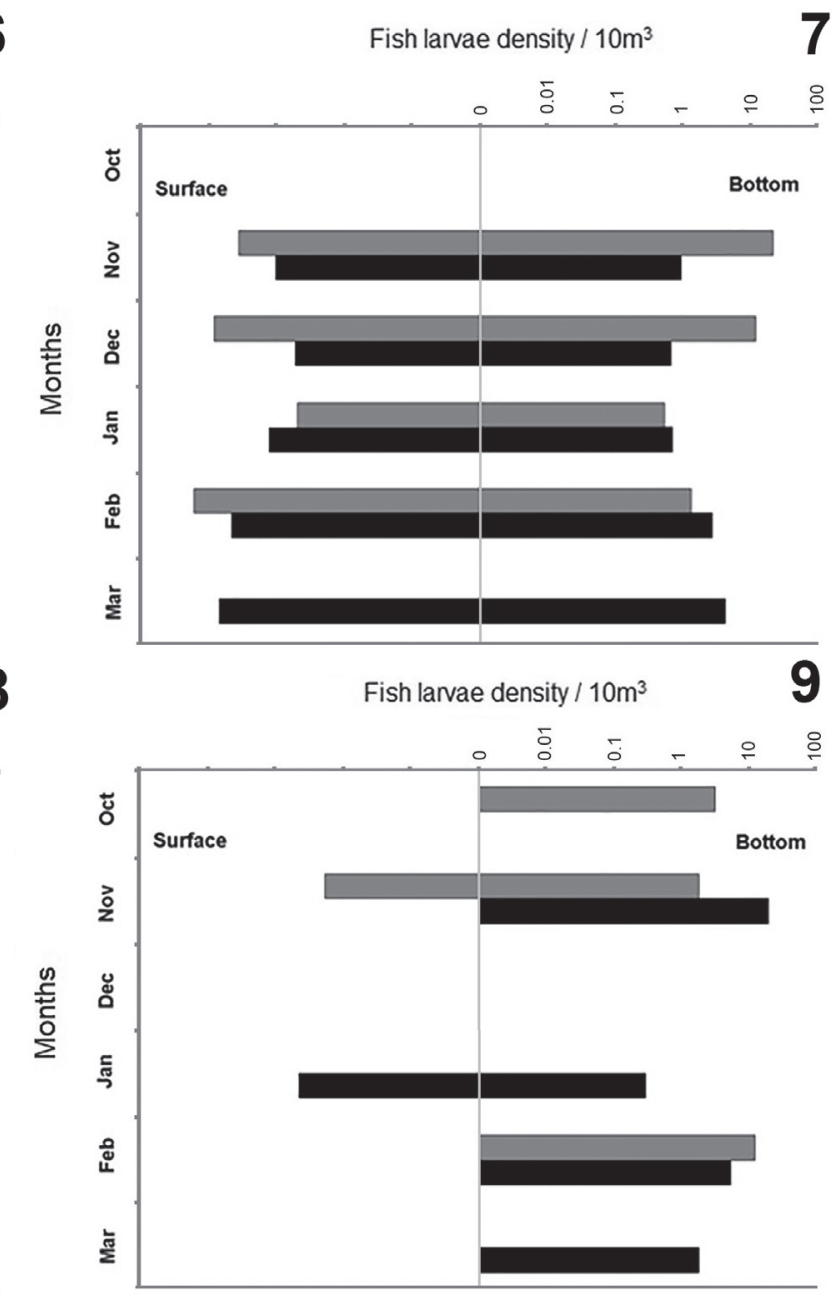

P. squamosissimus

Figs 6-9. Monthly larval density of H. edentatus (Spix, 1829) and P. squamosissimus (Heckel, 1840) per time: 8:00 pm (6), 4:00 am (7), 8:00 am (8) and 4:00 pm (9); and strata in the Xambrê Lagoon, Parque Nacional de Ilha Grande, Brazil during October 2010 to March 2011.

March, both on the surface at 4:00 pm (Fig. 13). The density of cladocerans varied from $810 \mathrm{ind} . / \mathrm{m}^{3}$ in December in the bottom $(8: 00 \mathrm{pm})$ to $71.2 \times 10^{3} \mathrm{ind} / \mathrm{m}^{3}$ in January on the surface (8:00 pm) (Fig. 10); there were no captures in December on the surface (4:00 pm) (Fig. 12). The density of copepods varied from $2.8 \times 10^{3} \mathrm{ind} / \mathrm{m}^{3}$ in October on the surface (4:00 pm) (Fig. 13) to $29.4 \times 10^{3} \mathrm{ind} / \mathrm{m}^{3}$ in January on the surface (4:00 am) (Fig. 11).

We found a significant difference in WMD $(p<$ $0.05, t$ test) between night and day for the larvae of $H$. edentatus, which shows that these larvae developed normal diel migration, remaining in the bottom during the day and ascending at night to superficial layers; the amplitude of vertical migration was $1.82 \mathrm{~m}$. We did not find significant differences in WMD between night and day for the larvae of P. squamosissimus and their amplitude of vertical migration was $1.54 \mathrm{~m}$. We only found differences in WMD between periods for cladocerans ( $p<0.05, t$ test). The amplitude of vertical migration of zooplankton was $0.46 \mathrm{~m}$ for rotifers, $0.88 \mathrm{~m}$ for cladocerans, and $0.34 \mathrm{~m}$ for copepods (Tab. II).
Monthly vertical distribution and WMD per strata and time and overlap between larvae of $H$. edentatus and $P$. squamosissimus and zooplankton are shown in figures 14-19. In general, throughout the months, the fish larvae remained in the deepest strata of the lagoon during the day. However, it was not possible to detect a pattern at night, as the larvae exhibited different distributions throughout the months in the water column.

The larvae of $H$. edentatus showed a significant difference ( $p<0.05, t$ test) in DVM in October, January, and February, remaining in deeper layers during the day and ascending to superficial layers during the night. We did not detect this behavior in other months (November and December), which showed no significant differences ( $p<0.05, t$ test) between night and day. The larvae of $P$. squamosissimus also showed a significant difference ( $p<$ $0.05, t$ test) in DVM in November, February, and March, but in other months the phenomenon was not significantly perceptible.

The zooplanktonic community exhibited different 
Tab. II. WMD of the H. edentatus (Spix, 1829), P. squamosissimus (Heckel, 1840), rotifers, cladocerans and copepods per time in the Xambrê Lagoon, Parque Nacional de Ilha Grande, Brazil during October 2010 to March 2011.

\begin{tabular}{lcccc}
\hline \multirow{2}{*}{ Fish larvae/Zooplankton } & \multicolumn{4}{c}{ Weighted mean depth (m) } \\
\cline { 2 - 5 } & \multicolumn{3}{c}{ Time (h) } \\
\cline { 2 - 5 } & $8: 00 \mathrm{pm}$ & $4: 00 \mathrm{am}$ & $8: 00 \mathrm{am}$ & $4: 00 \mathrm{pm}$ \\
\hline H. edentatus & 2.73 & 1.98 & 3.80 & 3.66 \\
P. squamosissimus & 2.50 & 1.66 & 3.07 & 3.20 \\
Rotifera & 1.72 & 1.75 & 2.18 & 1.84 \\
Cladocera & 1.60 & 1.53 & 2.29 & 2.41 \\
Copepoda & 1.64 & 1.71 & 1.98 & 1.88 \\
\hline
\end{tabular}
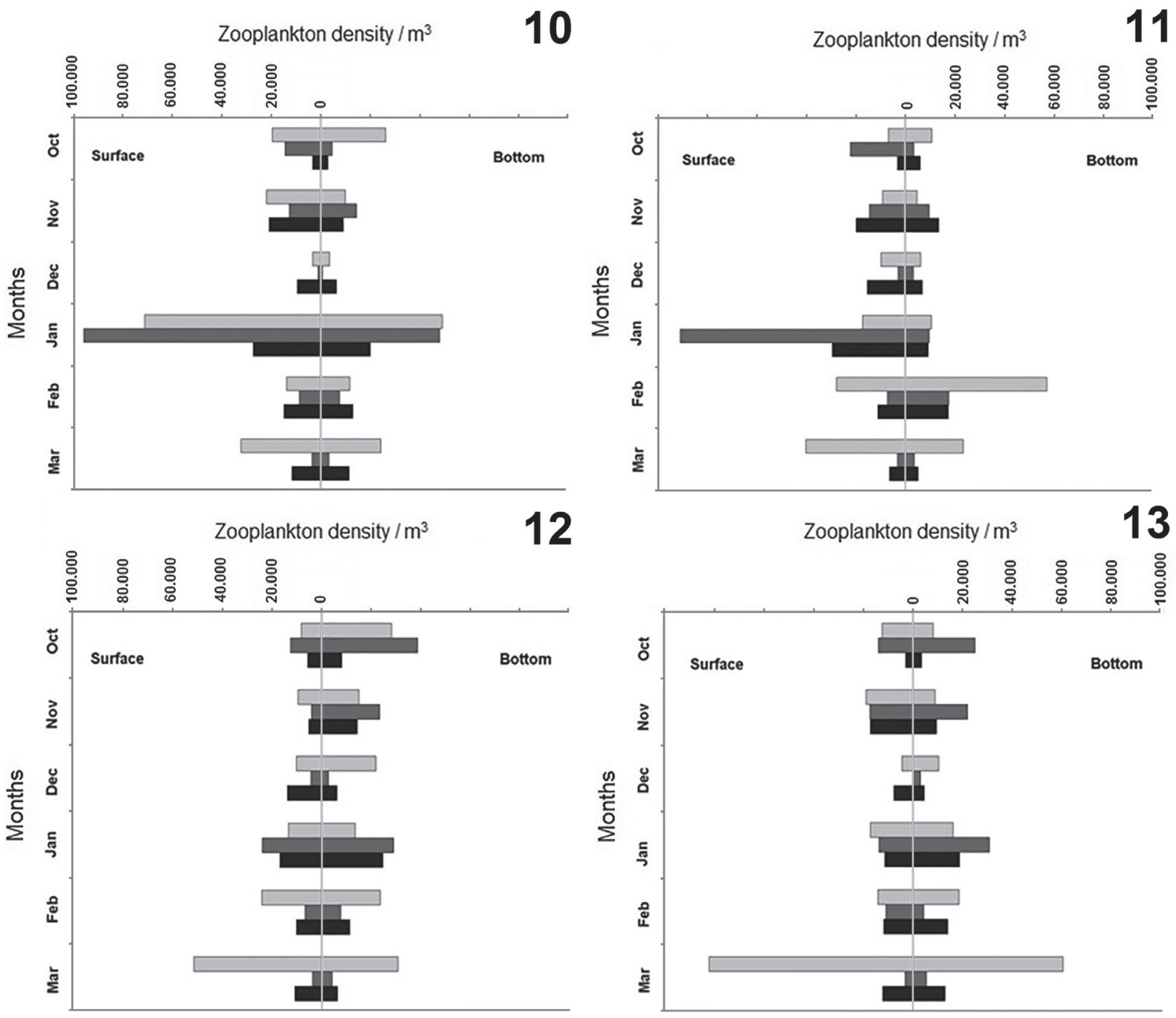

$\square$ Rotifera $\square$ Cladocera $\square$ Copepoda

Figs 10-13. Monthly density of rotifers, cladocerans, and copepods per time: 8:00 pm (10), 4:00 am (11), 8:00 am (12) and 4:00 pm (13); and strata in the Xambrê Lagoon, Parque Nacional de Ilha Grande, Brazil during October 2010 to March 2011.

distribution patterns, which varied between groups. DVM in rotifers was detected only in December; in other months it was not possible to detect this phenomenon, which shows that these organisms were found throughout the water column both at night and day. DVM in cladocerans was detected in five out of six months; the exception was March. In February, cladocerans showed reverse DVM, remaining during the day in superficial layers and migrating to deep layers at night. Copepods exhibited DVM in two out of six months (November and January); in other months this phenomenon was not detected.

The analysis of spatial overlap of zooplanktonic groups with the larvae of $H$. edentatus showed that at night the mean values of overlap were 0.46 for rotifers, 0.50 for 


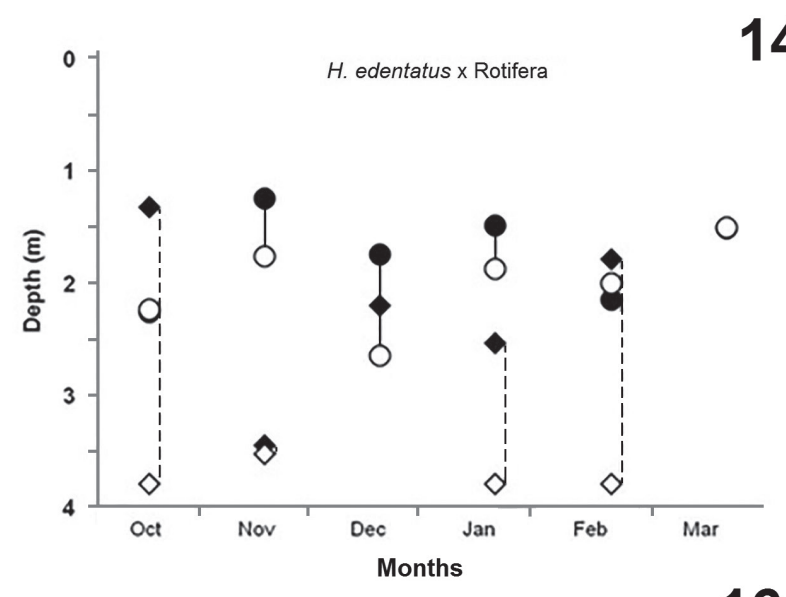

14
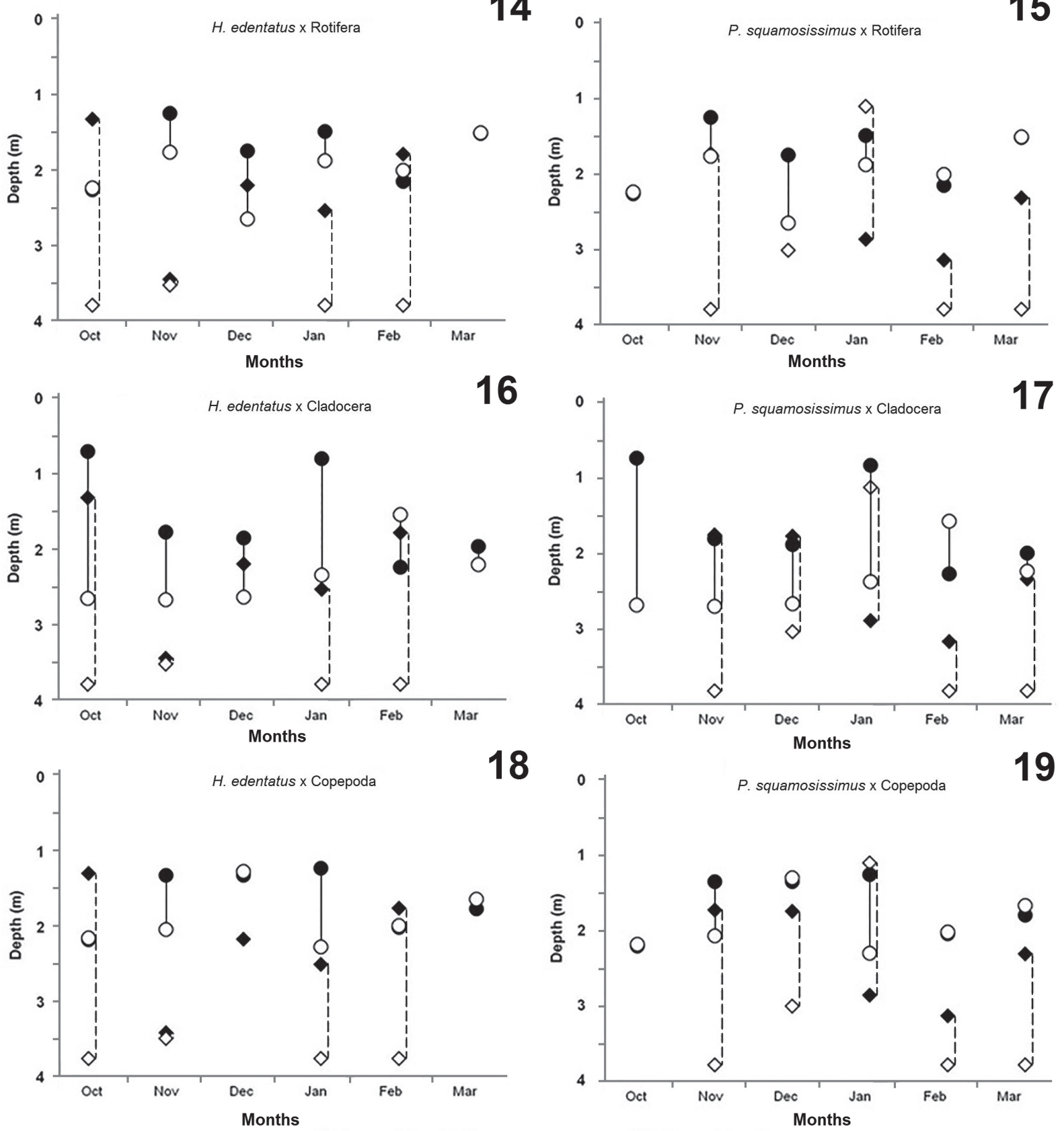

Prey - Day $\diamond$ Predator - Day Prey - Night $\diamond$ Predator - Night

Figs 14-19. WMD of fish larvae of the H. edentatus (Spix, 1829) and P. squamosissimus (Heckel, 1840) (predators) and rotifers, cladocerans and copepods (prey) combined samplings daytime and nighttime in the Xambrê Lagoon, Parque Nacional de Ilha Grande, Brazil during October 2010 to March 2011.

cladocerans, and 0.45 for copepods, whereas the mean values of overlap during the day were 0.42 for rotifers, 0.60 for cladocerans, and 0.56 for copepods. The analysis of spatial overlap of zooplanktonic groups with the larvae of $P$. squamosissimus showed that at night the mean values of overlap were 0.51 for rotifers, and 0.49 for cladocerans and copepods, respectively, whereas the mean values of overlap during the day were 0.50 for rotifers, 0.53 for cladocerans, and 0.47 for copepods. The spatial overlap analysis indicates that the zooplanktonic organisms reduced substantially their overlap with larvae of $H$. edentatus and P. squamosissimus, in particular the cladocerans that exhibited DVM in most months of study.

\section{DISCUSSION}

The data on vertical distribution of the ichthyoplankton and zooplankton communities in the 
Xambrê Lagoon evidence that these communities have different vertical distribution. Based on the differences found in the vertical distribution between day and night, we observed that the larvae of $H$. edentatus have the typical behavior of normal DVM, remaining in deeper layers during the day and ascending to superficial layers at night. It was not possible to detect a significant difference in distribution between strata for the larvae of $P$. squamosissimus, which preferred deep layers during the day and dispersed at night, occupying both the bottom and the surface. One possible explanation is that the larvae of P. squamosissimus explore a larger area of water than the larvae of $H$. edentatus. There are differences in posture and persistence during the attack to the prey and in feeding capacity. Larvae of piscivorous fish are larger, explore a larger volume of water per unit of time, and chase prey until capture (GERKING, 1994).

The most accepted explanation to DVM in freshwater fish is the light cycle, which comprises the light-dark cycle or diurnal-nocturnal cycle, which are separated by brief crepuscular periods (dusk, dawn) when light changes rapidly (MeHner, 2012). There is broad consensus that for several fish genera the decline in light during dusk stimulates ascension, whereas increasing light of dawn induces descend to hypolimnion (SCHEUERELL \& SChindler, 2003; Busch \& Mehner, 2009; Probst \& ECKMAnN, 2009; PicAPEdRa et al., 2015). However, some species do not show clear daily variations, but can form aggregations during the day and disperse at night (JENSEN et al., 2003).

The zooplanktonic community showed variations in DVM. Rotifers did not show DVM along months and were found nearly all over the water column during night and day. There is probably no DVM in rotifers because fish larvae do not prey on them, probably due to their small size, which makes them hard to visualize. In addition, rotifers have a broad variety of species, and each species may have a specific distribution in the water column. GoNZÁLEZ (1998) found a species-specific migratory pattern in rotifers in the presence of predators; some species showed a clear DVM pattern, whereas others did not show a migratory pattern. Some studies (OHMAN, 1983) suggest that rotifers can make well-defined movements at a small scale (less than 1 $\mathrm{m}$ ) for a period of several hours, which are negatively and significantly correlated to the daily movement of predators.

Among microcrustaceans, cladocerans exhibited DVM in most months. Several studies have been carried out in Brazilian lakes and reservoirs on the migratory behavior of this group, standing out Matsumura-TUNDisi et al. (1984) and Nogueira \& Panarelli (1997). However, in these studies the vertical migration of the cladocerans was explained mainly as a function of temperature. In the present study, though, abiotic factors, such as temperature, could not explain the vertical distribution of zooplanktonic organisms due to the small depth of the lagoon, where no stratification occurs. According to SperLing (1999), large and shallow water bodies are subject to cooling and warming processes caused by wind, which hinders the formation of vertical stratification. In the Xambrê Lagoon cladocerans could reduce spatial overlap with fish larvae during most months, except for two night periods in November and December with the larvae of $P$. squamosissimus. This shows that fish larvae may have been selectively predating cladocerans, triggering DVM in them, as a process to avoid predation. Studies by Ambrósio et al. (2001), AbujanRa \& Agostinho (2002) and MAKRAKIS et al. (2005), who analyzed the diet of $H$. edentatus in the reservoir of Itaipú hydropower plant, observed the predominance of cladocerans through the analysis of stomach contents. Conversely, as $P$. squamosissimus is considered a piscivorous and generalist species, it presents an ontogenetic variation in larval diet, in which the main item is zooplankton (GREY et al., 2002; MAKRAKIS et al., 2005).

Post \& Kitchell (1997) reported that larvae of predominantly zooplanktivorous fish have a limited trophic ontogeny and can remain their entire life with this feeding habit. Conversely, larvae of piscivorous fish have a fast ontogeny due to the presence of alternative prey and competition for larger components of the zooplankton. Likewise adult fish, the larvae cause significant impact on zooplankton populations in natural environments, reducing the population size of some organisms, and, consequently, increasing the population of others (GERKING, 1994).

In many pelagic communities, substantial predation pressure can come from more than one source, from both planktivorous fish and invertebrate predators. The presence of multiple predators may make the migratory response of zooplanktonic prey more complex, as reducing predation risk by one predator may simultaneously increase predation risk by another (NESBITT et al., 1996). WiLLIAMSON (1993) highlights that spatial overlap may play a fundamental role in the determination of which prey will be consumed by predators.

Copepods exhibited DVM in only two months. This variation in migratory amplitude may be explained by the fact that most captured organisms were juveniles (nauplii and copepodids). Studies such as those by BEZERRA-NeTO \& Pinto-CoelHo (2007) showed ontogenetic differences in the distribution of Thermocyclops inversus (Kiefer, 1936): nauplii exhibited almost no migratory behavior, whereas copepodids and adults exhibited migratory behavior. Such differences have usually been attributed to large individuals, which, because they are more evident and more susceptible to visual predators, migrate to avoid predation (NeILL, 1990).

Our results showed DVM in $H$. edentatus and $P$. squamosissimus, as their larvae try to aggregate during the day in the bottom of the lagoon and seek the surface at night. Among the zooplanktonic groups, rotifers exhibited almost no migratory behavior and in microcrustaceans (cladocerans and copepods) the normal DVM behavior was evident. The present study also showed that the spatial distribution of zooplanktonic groups may be associated with ichthyoplankton distribution and that the diel vertical migration of the zooplankton is important for reducing 
spatial overlap with predators, mainly in cladocerans. Although significant correlations were observed between the abiotic variables and the WMD of microcrustaceans at certain times of day, the effect of predation of fish larvae on zooplankton showed more important in this environment, because the small depth and isolation not allow great variation of abiotic factors seasonally and between strata the lagoon.

Acknowledgments. The authors thank the Consórcio Intermunicipal para a Conservação do Remanescente do Rio Paraná e Áreas de Influência (CORIPA) and the Grupo de Pesquisas em Recursos Pesqueiros e Limnologia (GERPEL) of the Universidade Estadual do Oeste do Paraná (UNIOESTE) for their support in field work.

\section{REFERENCES}

Abujanra, F. \& Agostinho, A. A. 2002. Dieta de Hypophthalmus edentatus (Spix, 1829) (Osteichthyes, Hypophthalmidae) e variações de seu estoque no reservatório Itaipú. Acta Scientiarum 24:401-410.

Aceves-Medina, G.; Saldierna-Martínez, R.; Hinojosa-Medina, A.; JimÉnez-Rosenberg, S. P. A.; HernándeZ-Rivas, M. E. \& MoralesÁvILA, R. 2008. Vertical structure of larval fish assemblages during diel cycles in summer and winter in the southern part of Bahía de La Paz, México. Estuarine, Coastal and Shelf Science 76:889-901.

Ambrósio, A. M.; Agostinho, A. A.; Gomes, L. C. \& OKADA, E. K. 2001. The fishery and fishery yield of Hypophthalmus edentatus (Spix, 1829), (Siluriformes, Hypophthalmidae), in the Itaipú reservoir, Paraná State, Brazil. Acta Limnologica Brasiliensia 13:93-105.

Bezerra-Neto, J. F. \& Pinto-Coelho, R. M. 2002. A influência da larva de Chaoborus brasiliensis (Theobald, 1901) (Diptera: Chaoboridae) na distribuição vertical da comunidade zooplanctônica da lagoa do Nado, Belo Horizonte, Minas Gerais. Acta Scientiarum 24:337-344.

2007. Diel vertical migration of the copepod Thermocyclops inversus (Kiefer, 1936) in a tropical reservoir: the role of oxygen and the spatial overlap with Chaoborus. Aquatic Ecology 41:535-545.

. 2012. Hydroacoustic assessment of fish and Chaoborus (Diptera-Chaoboridae) distribution in three Neotropical lakes. Acta Limnologica Brasiliensia 24:18-28.

Börng, W.; Wagner, A.; Voigt, H.; Deppe, T. \& Benndorf. J. 1998. Phytoplankton responses to grazing by Daphnia galeata in the biomanipulated Bautzen reservoir. Hydrobiology 389:101-114.

Bottrell, H. H.; Duncan, A.; Gliwicz, Z. M.; GrygiereK, E.; HerZig, A.; Hilbricht-LlkowsKa, A.; Kurazawa, H.; Larsson, P. \& WEGLENSKA, T. A. 1976. Review of some problems in zooplankton production studies. Journal of Zoology 24:419-456.

Busch, S. \& MeHNER, T. 2009. Hydroacoustic estimates of fish population depths and densities at increasingly longer time scales. International Review of Hydrobiology 94:91-102.

Ciannelli, L.; Dingsor, G. E.; Bogstad, B.; Ottersen, G.; Chan, K. S.; Guoseter, H.; Stiansen, J. E. \& Stensth, N. C. 2007. Spatial anatomy of species survival: effects of predation and climate-driven environmental variability. Ecology 88:635-646.

Daga, V. S.; Gogola, T. M.; Sanches, P. V.; Baumgartner, G.; Baumgartner, D. Delariva, R. L.; Piana, P. A. \& Gubiane, E. A. 2009. Fish Larvae Dynamics in Two Ponds with Different Degrees of Connection to the Paraná River, Paraná-Brazil. Neotropical Ichthyology 7:429-438.

Dodson, S. I. 1988. The ecological role of chemical stimuli for the zooplankton: predator-avoidance behavior in Daphnia. Limnology and Oceanography 33:1431-1439.

Elmoor-Loureiro ,M. A. L. 1997. Manual de identificação de cladóceros límnicos do Brasil. Brasília, Universa. 155p.

Frost, B. W. \& Bollens, S. M. 1992. Variability of diel vertical migration in the marine planktonic copepod Pseudocalanus newmani in relation to its predators. Canadian Journal of Fisheries and Aquatic Sciences 49:1137-1141.

Gerking, S. D. 1994. Feeding ecology of fish. San Diego, Academic. 416p.
GonzÁLEZ, M. J. 1998. Spatial segregation between rotifers and cladocerans mediated by Chaoborus. Hydrobiology 387:426-436.

Grey, J.; Thackeray, S. J.; Jones, R. I. \& Shine, A. 2002. Ferox Trout (Salmo trutta) as Russian dolls: complementary gut content and stable isotope analyses of the Loch Ness food web. Freshwater Biology 47:1235-1243.

HaYs, G. C. 2003. A review of the adaptive significance and ecosystem consequences of zooplankton diel vertical migrations. Hydrobiology 503:163-170.

Jensen, H.; Wright, P. J. \& MunK, P. 2003. Vertical distribution of presettled sandeel (Ammodytes marinus) in the North Sea in relation to size and environmental variables. Journal of Marine Science 60:1342-1351

Kempf, A.; Floeter, J. \& Temming, A. 2008. Predator prey overlap induced Holling Type III feeding response in the North Sea fish assemblage. Marine Ecology Progress Series 367:295-308.

Koste, W. 1978. Rotatoria die Rädertiere Mitteleuropas begründet von Max Voigt. Monogononta. Berlin, Gebrüder Borntraeger. 673p.

Lansac-Tôha, F. A.; Velho, L. F. M.; Higuti, J. \& Takahashi, E. M. 2002. Cyclopidae (Crustacea, Copepoda) from the Upper Paraná River Floodplain, Brazil. Brazilian Journal of Biology 62:125-133.

Lorke, A.; Mcginnis, D. F.; SPaAK, P. \& WÜESt, A. 2004. Acoustic observations of zooplankton in lakes using a Doppler current profiler. Freshwater Biology 49:1280-1292.

Makrakis, M. C.; Nakatani, K.; Bialetzki, A.; Sanches, P. V.; Baumgartner, G. \& Gomes, L. C. 2005. Ontogenetic shifts in digestive tract morphology and diet of fish larvae of the Itaipú Reservoir, Brazil. Environmental Biology of Fishes 72:99-107.

Matsumura-Tundisi, T. 1986. Latitudinal distribution of Calanoida copepods in freshwater aquatic systems of Brazil. Brazilian Journal of Biology 46:527-553.

Matsumura-Tundisi, T.; Tundisi, S. G. \& Tavares, L. S. 1984. Diel migration and vertical distribution of Cladocera in Lake D. Helvécio. Hydrobiology 113:299-306.

MeHNER, T. 2012. Diel vertical migration of freshwater fishes - proximate triggers, ultimate causes and research perspectives. Freshwater Biology 57:1342-1359.

Nakatani, K.; Agostinho, A. A.; Baumgartner, G.; Bialetzki, A.; Sanches, P. V.; Makrakis, M. C. \& Pavanelli, C. S. 2001. Ovos e larvas de peixe de água doce: Desenvolvimento e manual de identificação. Maringá, Eduem. 378p.

NeILL, W. E. 1990. Induced vertical migration in copepods as a defense against invertebrate predation. Nature 45:524-526.

Nesbitt, L. M.; Riessen, H. P. \& Ramcharan, C. W. 1996. Opposing predation pressures and induced vertical migration responses in Daphnia. Limnology and Oceanography 41:1306-1311.

Nogueira, M. G. \& Panarelli, E. 1997. Estuda da migração vertical das populações zooplanctônicas na represa de Jurumirim (rio Parapanema, São Paulo, Brasil). Acta Limnologica Brasiliensia 9:55-81.

Ohman, M. D. 1983. Reverse diel migration: an escape response from invertebrate predators. Science 220:1404-1407.

1990. The demographic benefits of diel vertical migration by zooplankton. Ecological Monographs 60:257-281.

Picapedra, P. H. S.; Lansac-TôHa, F. A. \& Bialetzki, A. 2015. Diel vertical migration and spatial overlap between fish larvae and zooplankton in two tropical lakes, Brazil. Brazilian Journal of Biology 75:352-361.

Post, D. M. \& KitchelL, J. F. 1997. Trophic ontogeny and life history effects on interactions between age-0 fishes and zooplankton. Archiv für Hydrobiologie, Advances in Limnology 49:1-12.

Previatelli, D. \& Santos-Silva, E. N. 2011. Predação de zooplâncton por peixes no lago Tupé, Manaus-AM. In: SAntos-Silva, E. N; Scudeller, V. V. \& Cavalcanti, M. J. eds. BioTupé: Meio Físico, Diversidade Biológica e Sociocultural do Baixo Rio Negro, Amazônia Central. Manaus, Rizoma Editorial, p.242-252.

Probst, W. N. \& Eckmann, R. 2009. The influence of light on the diel vertical migration of young-of-the-year burbot Lota lota in Lake Constance. Journal of Fish Biology 74:150-166.

REID, J. W. 1985. Chave de identificação e lista de referências bibliográficas para as espécies continentais sul americanas de vida livre da ordem Cyclopoida (Crustacea, Copepoda). Boletim Zoologia 9:17-143. 
Reis, R. E.; Kullander, S. O. \& Ferraris, C. J. 2003. Check list of the Freshwater Fishes of South and Central America. Porto Alegre, Edipucrs. 279p.

SCHeurell, M. D. \& SchindLer, D. E. 2003. Diel vertical migration by juvenile sockeye salmon: empirical evidence for the anti-predation window. Ecology 84:1713-1720.

Segers, H. 1995. Rotifera: The Lecanidae (Monogonta). Guides to the identification of the micro invertebrates of the continental water of the world. Netherlands, The Hague. $226 \mathrm{p}$.

SiH, A. 1987. Predator and prey lifestyles: an evolutionary and ecological overview. In: Kerfoot, W. C. \& SiH, A. eds. Predation: Direct and Indirect Impacts on Aquatics Communities. Hanover, University Press, p.389-436.

Sperling, E. 1999. Morfologia de lagos e represas. Belo Horizonte, Segrac. $137 \mathrm{p}$.

STATSOFt InC. 2005. STATISTICA for Windows (data analysis software system), version 7.1. Tulsa, Statsoft Inc.

Tamaki, A.; Mandal, S.; Agata, Y.; Aoki, I.; Suzuki, T.; Kanehara, H.; Aoshima, T.; Fukuda, Y.; Tsukamoto, H. \& Yanagi, T. 2010. Complex vertical migration of larvae of the ghost shrimp, Nihonotrypaea harmandi, in inner shelf waters of western Kyushu, Japan. Estuarine, Coastal and Shelf Science 86:125-136.
TANAKA, S. 1973. Stock assessment by means of ichthyoplankton surveys. FAO: Fisheries Technical Paper 8:33-51.

Williamson, C. E. 1993. Linking predation risk models with behavioral mechanisms: identifying population bottlenecks. Ecology 74:320-331.

Williamson, C. E. \& Stoeckel, M. E. 1990. Estimating predation risk in zooplankton communities: the importance of vertical overlap. Hydrobiology 198:125-131.

ZARET, T. M. 1984. Fish/Zooplankton interactions in Amazon floodplain lakes. Verhandlungen des Internationalen Verein Limnologie 22:1305-1309.

ZARET, T. M. \& SUFFERN, J. S. 1976. Vertical migration in zooplankton as a predator avoidance mechanism. Limnology and Oceanography 21:804-813. 